\title{
Does FMF have a property to protect children from obesity?
}

\author{
Faysal Gök ${ }^{1}$, İsmail Dursun², İbrahim Gökçe ${ }^{2}$
}

${ }^{1}$ Department of Pediatric Nephrology and Rheumatology, Gülhane Military Medical Academy, School of Medicine, Ankara, Turkey; faysalgok@yahoo.com

${ }^{2}$ Department of Pediatric Nephrology and Rheumatology, Gülhane Military Medical Academy, School of Medicine, Ankara, Turkey; drdursun@hotmail.com, gokcemd@yahoo.com

Received 20 November 2009; revised 11 January 2010; accepted 15 January 2010.

\begin{abstract}
Objectives: This study investigates the prevalence of obesity in children with familial Mediterranean fever (FMF). Material and Methods: We retrospectively reviewed the medical records of 70 patients with FMF whose cases had been followed in our Pediatric Nephrology and Rheumatology Unit. The height and weight measurements of children with FMF were obtained and body mass index was calculated. Results: The mean body mass index was $16.7 \pm 2.4$ in the boys, and $17.4 \pm 2.9$ in the girls. Nine of the children (five boys, four girls) were found to be overweight, a rate of $12.8 \%$ in FMF patients. Obesity was not detected in FMF patients. Conclusions: We think that there are some unligteening molecular mechanisms that prevent obesity in FMF patients. Due to the limited number of patients in this study, further research involving more patients are needed.
\end{abstract}

Keywords: Familial Mediterranean Fever; Obesity; Children; Adipocytokines

\section{INTRODUCTION}

Familial Mediterranean fever (FMF), an autosomal recessive disorder common in Mediterranean and Middle Eastern populations, especially in Sephardic Jewish, Armenian and Turkish populations, is characterized by recurrent episodes of fever, abdominal pain, joint pain, and less frequently, pleuritis, pericarditis and rash, described as erysipelas-like erythema [1]. The prognosis of this disease depends on the development of the amyloidosis of AA type with prominent renal involvement [2]. The molecular mechanism of FMF is still not clear. The gene causing FMF, known as MEFV (MEditerranean FeVer), has been mapped on the short arm of chromo- some 16 [3]. It has been shown that substantial subclinical inflammation occurs widely and over prolonged periods in patients with FMF, indicating that the relatively infrequent clinically overt attacks represent the tip of the iceberg in this disorder [4].

Obesity is characterized by a state of chronic low-grade inflammation [5]. The basis for this view is that increased circulating levels of several markers of inflammation, both pro-inflammatory cytokines and acute-phase proteins, are elevated in the obese; these markers include IL-6, the TNFa system, C-reactive protein (CRP) and haptoglobin [6]. Nevertheless, it is increasingly evident that the inflammatory state may be causal in the development of insulin resistance and the other disorders associated with obesity, such as hyperlipidaemia and metabolic syndrome [5]. While the general assumption is that inflammation is consequent to obesity, it has been suggested that obesity is in fact a result of inflammatory disease [6].

Although studies regarding the etiologic factors of FMF and obesity have been reported, the eligible etiology of neither FMF nor obesity is clear yet. The influence of FMF on the growth parameter has been reported [7-9]. According to literature, the prevalence of both diseases is high in the Turkish population $[10,11]$. Thus we aimed to show the relationship between the diseases and the prevalence of overweight and obesity in FMF patients.

\section{PATIENTS AND METHODS}

We retrospectively reviewed the medical records of 70 patients with FMF whose cases had been followed up in our Pediatric Nephrology and Rheumatology Unit. The diagnosis of FMF had been made according to the diagnostic criteria and mutational analysis $[12,13]$. Only patients who had homozygosity and/or compound heterozygosity for MEFV mutations were included in this study. Body height and weight were measured by trained paediatric specialists. For the measurements, the patients 
were dressed in light indoor clothing and bare feet or stockings. The subjects were weighed to the nearest 0.1 $\mathrm{kg}$ with an electronic scale (SECA 762; Vogel \& Hakle, Hamburg, Germany) calibrated daily at the beginning of each working day. Height was measured with a stadiometer in the vertical position, erect, with parallel feet and ankles, and with the shoulders and bottom touching the wall. The height and weight data were used to calculate the body mass index $(\mathrm{BMI})\left(\mathrm{kg} / \mathrm{m}^{2}\right)$ using the formula: weight $(\mathrm{kg})$ divided by height $(\mathrm{m})$ squared. The BMI normalized centile curves for Turkish children were applied to define obesity and the values of 95 percent or more were accepted as obesity [11].

\section{STATISTICAL ANALYSES}

All tests were performed using SPSS for Windows 15.0. The parameters with normal distribution were expressed as mean $\pm \mathrm{SD}$. Comparisons of means were performed with an unpaired t-test. Comparisons of proportions were performed with a Pearson-chi-squared test. A P value $<0.05$ was accepted as statistically significant.

\section{RESULTS}

The study population consisted of 70 children with FMF (34 boys, 36 girls). Table 1 shows the age distribution and anthropometric parameters of the FMF patients. The mean age of boys and girls was $8.9 \pm 3.5$ (range 5-18 years) and $9.4 \pm 3.1$ (range 5-16 years), respectively. The mean of BMI was $16.7 \pm 2.4$ in boys, $17.4 \pm 2.9$ in girls. Overweight was diagnosed in 9 (5 boys, 4 girls) and the prevalence of overweight is $12.8 \%$ in FMF patients. Obesity was not detected in FMF patients. The results of genotype of the patients with FMF are shown in Table 2.

\section{DISCUSSIONS}

In this study we investigated the prevalence of obesity in FMF patients. Obesity is a problem of public health and its prevalence is increasing rapidly worldwide [14]. The prevalence of obesity and overweight has been reported 9.7-12.8\% and 11.6-25\%, respectively, in Turkish children [11,15-17]. Regarding the study group, the number of obese children at least was expected to be seven, but none were found; and the $\mathrm{P}$ value $<0.05$ was statistically significant. The rate of overweight in the study group was the same as in Turkish healthy children.

Shortened growth is a frequent complication in the chronic inflammatory diseases of childhood [18]. Growth in children with FMF has been evaluated in three previous studies [7-9]. Savgan et al. reported that children with FMF have growth patterns no different from those of their healthy peers. Zung et al. showed that colchicine therapy has a positive effect on anthropometric
Table 1. Age distrubution and antropometric parameters of the patients with FMF.

\begin{tabular}{ccc}
\hline Variables & $\begin{array}{c}\text { FMF (boys) } \\
(\mathbf{n}=\mathbf{3 4})\end{array}$ & $\begin{array}{c}\text { FMF (girls) } \\
(\mathbf{n}=\mathbf{3 6})\end{array}$ \\
\hline Age (years) & $8,9 \pm 3,5$ & $9,4 \pm 3,1$ \\
BMI $\left(\mathrm{kg} / \mathrm{m}^{2}\right)$ & $16,7 \pm 2,4$ & $17,4 \pm 2,9$ \\
Overweight & 5 & 4 \\
\hline
\end{tabular}

Table 2. Major genotypes in FMF patients.

\begin{tabular}{cc}
\hline Mutations & $\mathbf{n}(\%)$ \\
\hline M694V-M694V & $28(40)$ \\
M694V-V726A & $13(18.5)$ \\
M694V-M680I & $11(15.7)$ \\
M694V-E148Q & $7(10)$ \\
M680I-M680I & $3(4.2)$ \\
V726A-E148Q & $2(2.8)$ \\
V726A-V726A & $1(1.4)$ \\
E148Q- E148Q & $1(1.4)$ \\
M694V/R761H & $1(1.4)$ \\
M680I/V726A & $1(1.4)$ \\
V726A/R761H & $1(1.4)$ \\
E148Q/R761H & $1(1.4)$ \\
Total & $70(100)$ \\
\hline
\end{tabular}

parameters in children with FMF. Turkmen et al. indicated that colchicine therapy caused a slight but significant increase in BMI. There was no obese child among the FMF subjects in this study. In the light of suggestions that obesity is in fact a result of inflammatory disease, we think that the chronic inflammatory situation alone is not enough to state the mechanism of the non-development of obesity in the FMF study group. The low-grade systemic inflammation in FMF patients may underlie the clustering of metabolic risk factors, but their role in children remains to be specified. The adipocytokines and cytokines appear to be important in this respect.

Leptin is secreted from adipocytes in response to changes in body fat and was initially suggested as a promising "anti-obesity" hormone. The interaction of leptin with its receptors controls body weight and daily energy consumption $[19,20]$. In the hypothalamus, leptin binds to receptors that stimulate anorexigenic peptides and inhibit orexigenic peptides [21]. Leptin declines rapidly during fasting. Therefore, leptin deficiency was perceived as a state of unmitigated starvation, leading to compensatory responses, such as hyperphagia, decreased metabolic rate and changes in hormone levels, designed to restore energy balance [22]. Leptin reduces intracellular lipid levels in skeletal muscle, liver and pancreatic beta cells, and thereby improving insulin sensitivity.

Unlike most adipokines, adiponectin expression and serum concentrations are reduced in obese and insulin-resistant states. Like leptin, adiponectin enhances insulin sensitivity. High adiponectin levels were found in 
association with high levels of HDL cholesterol and a low triglyceride-to-HDL ratio [23]. Adiponectin, implicated as having anti-inflammatory activity, is induced by PPARg (Peroxisome proliferator-activated receptors) agonism. Weight loss and caloric restriction have been found to increase adiponectin plasma levels and gene expression in white adipose tissue. Two case control studies in obesity-prone Pima Indians and in Caucasians suggested that individuals with high adiponectin concentrations are less likely to develop type- 2 diabetes than those with low concentrations [22]. Also, Saltevo et al. showed the significant negative relationship between adiponectin measured at adulthood and the relative change of BMI from childhood to adulthood [24].

It was shown that insulin resistance in lipoatrophic mice was fully reversed by a combination of physiological doses of adiponectin and leptin, but only partially by either adiponectin or leptin alone, suggesting that adiponectin and leptin work together to sensitize peripheral tissues to insulin. However, because globular adiponectin improves insulin resistance but not obesity in $o b / o b$ leptin-deficient mice, adiponectin and leptin appear to have distinct, albeit overlapping, functions [22].

Another adipokine studied in obese patients is omentin. Lean subjects have higher plasma omentin levels than do obese and overweight patients. Plasma omentin levels are inversely correlated with BMI, waist circumference, leptin levels and insulin resistance as measured by HOMA-R, and positively correlated with adiponectin and HDLcholesterol levels. Accordingly, omentin gene expression is decreased with obesity [25].

In addition, adipokines and many cytokines (especially IL-17A, IL-6, TNF-alfa) also were studied and found to be associated with lipid metabolism. It was shown that IL-17A inhibits adipocyte differentiation in human bone marrow mesenchymal stem cells, while promoting lipolysis of differentiated adipocytes [26].

In conclusion, the chronic inflammatory situation alone is not sufficient to state the mechanism of the nondevelopment of obesity in FMF patients. It is thought that some unligteening molecular mechanisms are involved in the interaction between cytokines and adipocytokines preventing obesity in FMF patients. Due to the limited number of patients in this study, further research with a greater number of patients looking at the wide range of adipocytokines and cytokines known to be associated with lipid metabolism and obesity are needed to confirm this speculation and establish the fundamentals of the non-development of obesity in FMF patients.

\section{REFERENCES}

[1] Sohar, E., Gafni, J., Pras, M. and Heller, H. (1967) Familial Mediterranean fever: A survey of 470 cases and review of the literature. American Journal of Medicine, 43,

\section{7-253.}

[2] Hashkes, P.J. (2002) Amyloidosis and familial Mediterranean fever. In: Rudolph, C.D., Rudolph, A.M., Hostetter, M.K., Lister, G., Siegel, N.J. (eds), Rudolph's Pediatrics (21st Editon), McGraw-Hill, New York, 864-866.

[3] Pras, M., Zemer, D., Langewitz, P. and Sohar, E. (1992) Familial Mediterranean fever: A genetic disorder prevalent in Sepharadi Jews. In: Bonne-Tamir, B., Adam, A. (eds), Genetic Diversity Among Jews: Diseases and Markers at the DNA Level, Oxford University Press, Oxford, 223-227.

[4] Ozçakar, Z.B., Yalçinkaya, F., Yüksel, S., Acar, B., Gökmen, D. and Ekim, M. (2006) Possible effect of subclinical inflammation on daily life in familial Mediterranean fever. Clinical Rheumatology, 25, 149-152.

[5] Yudkin, J.S. (2003) Adipose tissue, insulin action and vascular disease: Inflammatory signals. International Journal of Obesity and Related Metabolic Disorders, 27, 25-28.

[6] Das, U.N. (2001) Is obesity an inflammatory condition? Nutrition, 17, 953-966.

[7] Savgan-Gürol, E., Kasapçopur, O., Hatemi, S., Ercan, O., Caliskan, S., Sever, L., Ozdogan, H. and Arisoy, N. (2001) Growth and IGF-1 levels of children with familial Mediterranean fever on colchicine treatment. Clinical and Experimental Rheumatology, 19, 72-75.

[8] Türkmen, M., Soylu, O.B., Kasap, B., Güneş, S., Tüfekçi, O., Soylu, A., Erçal, D. and Kavukçu, S. (2008) Growth in familial mediterranean fever: Effect of attack rate, genotype and colchicine treatment. Journal of Pediatric Endocrinology and Metabolism, 21, 789-792.

[9] Zung, A., Barash, G., Zadik, Z. and Barash, J. (2006) Familial Mediterranean fever and growth: Effect of disease severity and colchicine treatment. Journal of Pediatric Endocrinology and Metabolism, 19, 155-160.

[10] Onen, F., Sumer, H., Turkay, S., Akyurek, O., Tunca, M. and Ozdogan, H. (2004) Increased frequency of familial Mediterranean fever in Central Anatolia, Turkey. Clinical and Experimental Rheumatology, 22, 31-33.

[11] Bundak, R., Furman, A., Gunoz, H., Darendeliler, F., Bas, F. and Neyzi, O. (2006) Body mass index references for Turkish children. Acta Paediatrica, 95, 194-198.

[12] Livneh, A., Langevitz, P., Zemer, D., Kees, S. and Lidav, T. (1997) Criteria for the diagnosis of familial Mediterranean fever. Arthritis and Rheumatism, 40, 1879-1885.

[13] Duşunsel, R., Dursun, I., Gündüz, Z., Poyrazoğlu, M.H., Gürgöze, M.K. and Dundar, M. (2008) Genotypephenotype correlation in children with familial Mediterranean fever in a Turkish population. Pediatrics International, 50, 208-212.

[14] World Health Organisation (1998) Obesity: Preventing and managing the global epidemic. Report of $A W H O$ Consultation, Geneva, 3-5 June 1997 (WHO/NT/98.1).

[15] Kocaoglu, B.A. and Köksal, O. (1985) The effect of socioeconomic conditions on growth, development and obesity among adolescents in Turkey. Journal of Nutrition and Dietetics, 14, 25-37.

[16] Cinaz, P., Çamurdan, O. and Maral, I. (2003) 6-16 yaş arası 12.589 çocukta obezite sıklığı ve risk faktörleri. VIII. Ulusal Pediatrik Endokrinoloji Kitabl, 230.

[17] Simsek, E., Akpinar, S., Bahcebasi, T., Senses, D.A. and Kocabay, K. (2008) The prevalence of overweight and obese children aged 6-17 years in the West Black Sea re- 
gion of Turkey. International Journal of Clinical Practice, 62, 1033-1038.

[18] Simon, D., Fernando, C., Czernichow, P. and Prieur, A.M. (2002) Linear growth and final height in patients with systemic juvenile idiopathic arthritis treated with longterm glucocorticoids. Journal of Rheumatology, 29, 1296-1300.

[19] Campfield, L.A., Smith, F.J., Guisez, Y., Devos, R. and Burn, P. (1995) Recombinant mouse OB protein: Evidence for a peripheral signal linking adiposity and central neural networks. Science, 269, 546-549.

[20] Halaas, J.L., Gajiwala, K.S., Maffei, M., Cohen, S.L., Chait, B.T., Rabinowitz, D., Lallone, R.L., Burley, S.K. and Friedman, J.M. (1995) Weight-reducing effects of the plasma protein encoded by the obese gene. Science, 269, 543-546.

[21] Ahima, R.S., Saper, C.B., Flier, J.S. and Elmquist, J.K. (2000) Leptin regulation of neuroendocrine systems. Front Neuroendocrinol, 21, 263-307.

[22] Ronti, T., Lupattelli, G. and Mannarino, E. (2006) The endocrine function of adipose tissue: An update. Clinical Endocrinology, 64, 355-365.
[23] Winer, J.C., Zern, T.L., Taksali, S.E., Dziura, J., Cali, A.M., Wollschlager, M., Seyal, A.A., Weiss, R., Burgert, T.S. and Caprio, S. (2006) Adiponectin in childhood and adolescent obesity and its association with inflammatory markers and components of the metabolic syndrome. Journal of Pediatric Endocrinology and Metabolism, 91, 4415-4423.

[24] Saltevo, J., Laakso, M., Jokelainen, J., KeinänenKiukaanniemi, S., Kumpusalo, E. and Vanhala, M. (2008) Levels of adiponectin, C-reactive protein and interleukin-1 receptor antagonist are associated with insulin sensitivity: A population-based study. Diabetes/Metabolism Research and Reviews, 24, 378-383.

[25] Antuna-Puente, B., Feve, B., Fellahi, S. and Bastard, J.P. (2008) Adipokines: The missing link between insulin resistance and obesity. Diabetes and Metabolism, 34, 2-11.

[26] Shin, J.H., Shin, D.W. and Noh, M. (2009) Interleukin-17A inhibits adipocyte differentiation in human mesenchymal stem cells and regulates pro-inflammatory responses in adipocytes. Biochemical Pharmacology, 77, 1835-1844. 